\title{
Suppressive effects of natural reduced waters on alloxan-induced apoptosis and type 1 diabetes mellitus
}

\author{
Yuping Li · Takeki Hamasaki · Kiichiro Teruya • Noboru Nakamichi · \\ Zbigniew Gadek • Taichi Kashiwagi • Hanxu Yan • Tomoya Kinjo • \\ Takaaki Komatsu · Yoshitoki Ishii · Sanetaka Shirahata
}

Received: 25 July 2011/Accepted: 18 November 2011/Published online: 6 December 2011

(C) Springer Science+Business Media B.V. 2011

\begin{abstract}
Insulin-producing cells express limited activities of anti-oxidative enzymes. Therefore, reactive oxygen species (ROS) produced in these cells play a crucial role in cytotoxic effects. Furthermore, diabetes mellitus (DM) development is closely linked to higher ROS levels in insulin-producing cells. Hita Tenryosui Water ${ }^{\circledR}$ (Hita T. W., Hita, Japan) and Nordenau water (Nord. W., Nordenau, Germany), referred to as natural reduced waters (NRWs), scavenge ROS in cultured cells, and therefore, might be a possibility as an alternative to conventional pharma-
\end{abstract}

Y. Li · T. Hamasaki · K. Teruya · T. Kashiwagi ·

T. Komatsu $\cdot$ S. Shirahata $(\bowtie)$

Department of Bioscience and Biotechnology,

Faculty of Agriculture, Kyushu University,

Fukuoka 812-8581, Japan

e-mail: sirahata@grt.kyushu-u.ac.jp

Y. Li

School of Life Science, Jiangxi Science \& Technology

Normal University, Nanchang 330013, China

K. Teruya $\cdot$ H. Yan $\cdot$ T. Kinjo

Graduate School of Systems Life Sciences, Kyushu

University, Fukuoka 812-8581, Japan

N. Nakamichi · Y. Ishii

Hita Tenryosui Co. Ltd., Nakanoshima-machi,

Hita 877-0074, Japan

Z. Gadek

Centre for Holistic Medicine and Naturopathy,

57392 Nordenau, Germany cological agents against DM. Therefore, this study aimed to investigate the role of NRWs in alloxan (ALX)-induced $\beta$-cell apoptosis as well as in ALXinduced diabetic mice. NRWs equally suppressed DNA fragmentation levels. Hita T. W. and Nord. W. ameliorated ALX-induced sub- $\mathrm{G}_{1}$ phase production from approximately $40 \%$ of control levels to 8.5 and $11.8 \%$, respectively. NRWs restored serum insulin levels $(p<0.01)$ and reduced blood glucose levels $(p<0.01)$ in ALX-induced mice. Hita T. W. restored tissue superoxide dismutase (SOD) $(p<0.05)$ activity but not tissue catalase activity. Hita T. W. did not elevate SOD or catalase activity in HIT-T15 cells. Nord. W. restored SOD $(p<0.05)$ and catalase $(p<0.05)$ activity in both cultured cells and pancreatic tissue to normal levels. Even though variable efficacies were observed between Hita T. W. and Nord. W., both waters suppressed ALX-induced DM development in CD-1 male mice by administering NRWs for 8 weeks. Our results suggest that Hita T. W. and Nord. W. protect against ALX-induced $\beta$-cell apoptosis, and prevent the development of ALXinduced DM in experimental animals by regulating ALX-derived ROS generation and elevating antioxidative enzymes. Therefore, the two NRWs tested here are promising candidates for the prevention of DM development.

Keywords Alloxan - Apoptosis - HIT-T15 cells · Reactive oxygen species - Natural reduced water . Type 1 diabetes mellitus 


$\begin{array}{ll}\text { Abbreviations } \\ \text { NRW } & \text { Natural reduced water } \\ \text { UPW } & \text { Ultra pure water } \\ \text { CNMW } & \text { Commercialized natural mineral water } \\ \text { MW } & \text { Mineral water } \\ \text { TUNEL } & \begin{array}{l}\text { Terminal deoxynucleotidyl-transferase-medi } \\ \text { ated dUTP nick-end labeling }\end{array} \\ & \text { Diabetes mellitus } \\ \text { DM } & \text { Type 1 diabetes mellitus } \\ \text { T1DM } & \text { Type 2 diabetes mellitus } \\ \text { T2DM } & \text { Reactive oxygen species } \\ \text { ROS } & \text { Glutathione } \\ \text { GSH } & \text { Superoxide dismutase } \\ \text { SOD } & \text { Ethylenediaminetetraacetic acid } \\ \text { EDTA } & \text { Bovine serum albumin } \\ \text { BSA } & \text { Fetal bovine serum } \\ \text { FBS } & \text { Hank's balanced salt solution } \\ \text { HBSS } & \text { 4-[2-hydroxyethyl]-1- } \\ \text { HEPES } & \text { piperazineethanesulfonic acid } \\ & \text { Phosphate buffered saline } \\ \text { PBS } & \text { Propidium iodide } \\ \text { PI } & \text { Terminal deoxynucleotidyl transferase } \\ \text { TdT } & \text { Alloxan } \\ \text { ALX } & \end{array}$

\section{Introduction}

Diabetes mellitus (DM), comprising type 1 (T1DM) and type 2 (T2DM), is one of the major health problems in human society and 30,000 people are reported to be diagnosed with T1DM worldwide every year (Bresson and von Herrath 2007). The mechanism of pancreatic $\beta$-cell loss is thought to be caused mainly by apoptosis in T1DM (Eizirik and Darville 2001; Cnop et al. 2005); while apoptosis or necrosis is suggested to be involved in T2DM development. In T1DM, $\beta$-cell loss by apoptosis leads to insulin deficiency and hyperglycemia (Cnop et al. 2005). Hyperglycemic conditions promote reactive oxygen species (ROS) formation in tissues (Valko et al. 2007). Such ROS are a major factor of pancreatic $\beta$-cell loss because they express low levels of antioxidant enzymes (Lenzen et al. 1996; Valko et al. 2007). Furthermore, other studies have reported that ROS contribute to $\beta$-cell dysfunction and disease progression by oxidative damage to bio-molecules including DNA (Yamamoto et al. 1981; Takasu et al. 1991;
Kaneto et al. 1996). These data strongly support the idea that controlling ROS levels could reduce the incidence of DM as well as associated complications. Indeed, previous studies have reported the feasibility of this idea by overexpression of mitochondrial catalase and/or superoxide dismutase (SOD) in pancreatic $\beta$-cells (Lortz and Tiedge 2003; Gurgul et al. 2004; Lortz et al. 2005). Although pharmacological agents are currently used to control glycemic conditions, some of these are often accompanied by adverse side effects (Nathan 2007; Nissen and Wolski 2007; Yaturu et al. 2007). Therefore, there is a strong demand for obtaining effective and safe hypoglycemic agents.

Daily water intake is a basic requirement for the maintenance of our life and health. In particular, mineral constituents of the water affect health status (Rylander 2008). Natural bottled mineral waters are popular compared with tap water because of their good taste and/or contained minerals thought to be beneficial for health. Several elements such as magnesium, vanadium, lithium, and silicon have been considered beneficial for preventing hypertension (Tubek 2006). Recently, a group of waters referred to as natural reduced waters (NRWs) such as Hita TenryosuiWater $^{\circledR}$ (Hita T. W.), which is drawn from deep underground in Hita, Oita, Japan, and Nordenau water (Nord. W.), spring water in Nordenau village in Germany, has attracted attention because these waters are claimed to exert beneficial effects for several diseases including DM. These NRWs have been reported to scavenge intracellular ROS in L6 myotubes (Shirahata et al. 2001) and HIT-T15 cells (Li et al. 2002). Previous studies have also demonstrated that NRWs protect against alloxan (ALX)-induced DNA fragmentation and enhance glucose-stimulated insulin secretion from ALX-damaged pancreatic $\beta$-cells ( $\mathrm{Li}$ et al. 2002). In addition, Hita T. W. stimulates 2-DG uptake into L6 myotubes even in the absence of insulin (Oda et al. 1999). Nord. W. has also been reported to improve conditions of T2DM patients when approximately $2 \mathrm{~L}$ of this water is consumed daily (Gadek et al. 2006). Based on these results, there appears to be a new function inherent to some of the NRWs though intrinsic factor(s) yet to be elucidated.

Previous studies on Hita T. W. and Nord. W. suggest that these waters have the potential to be used as therapeutic and/or preventive agents against DM. However, the data available to date are mostly 
confined to a cellular level and little is known regarding the usefulness of NRWs in vivo. We report that NRWs exert protective effect against ALXinduced apoptotic $\beta$-cell death and development of T1DM in mice.

\section{Materials and methods}

Reagents

Roswell Park Memorial Institute (RPMI) 1640 medium was purchased from Nissui Pharmaceutical Co. (Tokyo, Japan). Propidium iodide (PI) and ALX were purchased from Sigma Chemical Co. (St. Louis, MO). DNase-free RNase, proteinase K, 4-[2-hydroxyethyl]-1-piperazineethanesulfonic acid (HEPES), fetal bovine serum (FBS), bovine serum albumin (BSA), trichloroacetic acid (TCA), penicillin, streptomycin, and all other chemicals were obtained from Wako Pure Chemical Industries (Osaka, Japan).

Mineral waters and medium preparation

Hita T. W. was obtained from Hita Tenryosui Co. in Japan. Nord. W. was kindly supplied by Mr. Theo Tommes in Nordenau in Germany. Commercialized natural mineral water (CNMW) from Kagoshima Prefecture was purchased from the local market in Japan. NMWs have the following physical properties: for Hita T. W., pH of $7.29 \pm 0.02$ and Eh of $410.33 \pm$ $10.41 \mathrm{mV}$; for Nord. W., pH of $7.98 \pm 0.01$ and Eh of $431.00 \pm 18.25 \mathrm{mV}$; for CNMW, $\mathrm{pH}$ of $7.87 \pm 0.00$ and Eh of $380.33 \pm 10.12 \mathrm{mV}$. Oxidation-reduction potential (ORP) values are expressed as hydrogen electrode potential (Eh) following the instruction manual provided by the manufacture (Device type: HM-14P, ORP electrode: PTS-2019C, TOA-DKK Co. Japan). Eh value is the sum of measured value $(\mathrm{mV})$ and reference single electrode potential value of $206 \mathrm{mV}$ at $25^{\circ} \mathrm{C}$. The radioactivity of Hita $\mathrm{T}$. W. and Nord. W due to Ra or Rn was not detected. In this study, NRWs and CNMW are collectively called mineral water (MW). Ultra pure water (UPW) was prepared by a Millipore filtration system and used as a control. To investigate the effects of MWs on ALXinduced apoptosis in HIT-T15 cells, medium was prepared using each MW in place of UPW.
Cell culture

The hamster pancreatic $\beta$-cell line, HIT-T15, was purchased from Dainippon Pharmaceutical Co. (Tokyo, Japan). Falcon dishes were used to maintain the cells in medium supplemented with $10 \%$ FBS/ RPMI1640, 2 mM L-glutamine, 100 IU penicillin-G and $100 \mu \mathrm{g} / \mathrm{mL}$ streptomycin at $37^{\circ} \mathrm{C}$ in a humidified atmosphere of $5 \% \mathrm{CO}_{2}$. For the estimation of intracellular catalase and SOD activity, the cells were subcultured in a 24-well plate at a density of $1 \times 10^{5}$ cells/ well. For DNA fragmentation analysis, sub- $\mathrm{G}_{1}$ phase assay and TUNEL assay, the cells were sub-cultured in a 6 -well plate at a density of $2 \times 10^{5}$ cells/well. The culture media were replaced every $48 \mathrm{~h}$ throughout the cell growth period. When the cell density reached approximately $80 \%$ confluence, they were used for the various studies.

Sub- $\mathrm{G}_{1}$ phase assay

Cell cycle analysis was performed following a previously published method (Nicoletti et al. 1991). Briefly, HIT-T15 cells were pre-incubated with medium containing each MW for $24 \mathrm{~h}$ and were replaced by Hank's balanced salt solution (HBSS; $137 \mathrm{mM} \mathrm{NaCl}$, $5.4 \mathrm{mM} \mathrm{KCl}, 1 \mathrm{mM} \mathrm{MgCl}, 2 \mathrm{mM} \mathrm{CaCl}, 10 \mathrm{mM}$ HEPES, and $1 \mathrm{~g} / \mathrm{L}$ BSA) buffer made of each MW followed by $30 \mathrm{~min}$ of incubation. After the addition of $1 \mathrm{mM}$ ALX, cells were further incubated for $4 \mathrm{~h}$. The cells were harvested by trypsinization and centrifugation at $200 \times g$ for $5 \mathrm{~min}$. The cell pellets were then gently resuspended in $0.5 \mathrm{~mL}$ phosphate buffered saline (PBS) followed by overnight fixation in $2 \mathrm{~mL}$ of $70 \%$ ethanol at $-20{ }^{\circ} \mathrm{C}$. Fixed cells were centrifuged at $200 \times g$ for $5 \mathrm{~min}$ to remove cell debris. The cell pellets were resuspended in $100 \mu \mathrm{L}$ PCB buffer (0.2 $\mathrm{M} \mathrm{Na}_{2} \mathrm{HPO}_{4}$ and $0.1 \mathrm{M}$ citric acid), incubated for $20 \mathrm{~min}$ and then centrifuged at $200 \times g$ for $5 \mathrm{~min}$. The supernatants were collected for DNA ladder analysis and the cell pellets were used for propidium iodide (PI) staining. The cell pellets were incubated in $1 \mathrm{~mL}$ PI/RNase A/PBS staining solution $(10 \mu \mathrm{g} / \mathrm{mL}$ PI and $10 \mu \mathrm{g} / \mathrm{mL}$ RNase A) at $25^{\circ} \mathrm{C}$ for $20 \mathrm{~min}$ in the dark. Stained cells were analyzed using a flow cytometer (EPICS XL System II-JK, Beckman Coulter, USA). A wave length of $488 \mathrm{~nm}$ was used as a source of excitation. Fluorescence emission was collected through a $610 \mathrm{~nm}$ band pass filter for PI. PI 
fluorescence data were collected on a linear scale. Ten thousand cells were evaluated for each sample. The percentage of apoptotic cells was determined using the Cell-Quest software program equipped in the EPICS XL System II-JK (Beckman Coulter, USA).

DNA fragmentation analysis

HIT-T15 cell treatment with $1 \mathrm{mM}$ ALX and cell supernatant collection were the same as described for the sub- $\mathrm{G}_{1}$ phase assay. The supernatant was treated with RNase $\mathrm{A}(10 \mu \mathrm{g} / \mathrm{mL})$ at $37{ }^{\circ} \mathrm{C}$ for $1 \mathrm{~h}$ and then with proteinase $\mathrm{K}(10 \mu \mathrm{g} / \mathrm{mL})$ at $50{ }^{\circ} \mathrm{C}$ for $30 \mathrm{~min}$. DNA in the supernatant was precipitated with an equal volume of isopropanol at $-20{ }^{\circ} \mathrm{C}$ overnight and collected by centrifuging at $20,400 \times g$ for $15 \mathrm{~min}$. After removing the supernatant, the precipitated DNA was centrifuged again at $20,400 \times g$ for $5 \mathrm{~min}$ and the residual supernatant was removed as completely as possible. Finally, the low molecular weight DNA was dissolved in $20 \mu \mathrm{L}$ TE buffer (1 mM EDTA and $10 \mathrm{mM}$ Tris-HCl, pH 8.0) at $25{ }^{\circ} \mathrm{C}$ for $30 \mathrm{~min}$. DNA was electrophoresed in $2.0 \%$ agarose gels for $30 \mathrm{~min}$ at $100 \mathrm{~V}$. The gels were photographed under ultraviolet light.

\section{Determination of apoptosis}

Apoptotic cells were determined using an ApoAlert DNA fragmentation assay kit (Clontech laboratories Inc., Mountain View, CA) closely following the terminal deoxynucleotidyl transferase (TdT)-mediated dUTP nick-end-labeling (TUNEL) manual. Briefly, the cells for the assay were harvested by gently scraping and washing in PBS, and then they were counted. The cells were resuspended in fresh, pre-chilled $1 \%$ formaldehyde on ice and incubated for $20 \mathrm{~min}$. The cells were precipitated again by centrifugation and washed once with PBS. The cells were fixed with $70 \%$ ethanol at $-20{ }^{\circ} \mathrm{C}$ overnight. Following centrifugation, the cell samples were washed with PBS and treated with $0.2 \%$ Triton X-100 in PBS for $5 \mathrm{~min}$ at room temperature. The cells were washed with PBS after centrifugation and resuspended in TdT reaction buffer and incubated at $37{ }^{\circ} \mathrm{C}$ for $1 \mathrm{~h}$, and then the reaction was terminated by adding $20 \mathrm{mM}$ EDTA. The cells were washed with $0.1 \%$ Triton $\mathrm{X}-100 / \mathrm{BSA} / \mathrm{PBS}$ solution followed by suspending in $500 \mu \mathrm{L}$ PBS containing $0.5 \mu \mathrm{g} / \mathrm{mL}$ of PI and $0.5 \mathrm{mg} /$ $\mathrm{mL}$ of DNase-free RNase A. The cells were incubated at room temperature for $20 \mathrm{~min}$ prior to measurement. Cellular fluorescence was measured using flow cytometry with the EPICS XL System II-JK (Beckman Coulter, USA).

\section{Estimation of cellular catalase and SOD activity}

For the estimation of anti-oxidative enzyme activity in the cell, the supernatant fractions were prepared as follows. HIT-T15 cells treated with MWs and/or ALX were harvested by gentle scraping and homogenized in $500 \mu \mathrm{L}$ of $50 \mathrm{mM}$ potassium phosphate buffer $(\mathrm{pH} 7.0)$ containing $1 \mathrm{mM}$ EDTA, and then centrifuged at $10,000 \times g$ for $15 \mathrm{~min}$ at $4{ }^{\circ} \mathrm{C}$. Catalase-mediated decomposition of hydrogen peroxide was measured by ultraviolet spectroscopy at $240 \mathrm{~nm}$ (Claiborne 1985). SOD activity was estimated using an SOD assay kit following the manufacturer's instructions (SOD Activity Detection Kit [NBT reduction method], Wako Pure Chemicals Industries, Ltd. Osaka, Japan). Protein concentration was determined by the method of Lowry using BSA as the standard (Lowry et al. 1951).

\section{Experimental animals}

Healthy, adult male ICR (CD 1-strain) mice were purchased from Charles River Japan Inc. (Tokyo, Japan). Animals were approximately 5 weeks of age, weighing approximately $30 \mathrm{~g}$ at receipt. After a 7-day acclimation period, 60 mice were randomly assigned into five groups of 12 mice to ensure homogeneity of body weights across the groups. Grouped mice were housed in a room maintained at an average daily temperature of $22-25{ }^{\circ} \mathrm{C}$, an average daily relative humidity of 40-60\% and on a $12 \mathrm{~h}$ light/dark cycle (light phase from 7:00 am to 7:00 pm). Mice were fed with balanced mice feed (CRF-2) purchased from Charles River Japan Inc. The feed and water were consumed ad libitum throughout the acclimation and study periods. Prior to each study, the mice were fasted for $15-18 \mathrm{~h}$.

\section{Animal treatments}

Grouped mice were given MWs and UPW daily for 4 weeks. At the end of the 4 th week, mice were fasted for $18 \mathrm{~h}$, and ALX was administered by three consecutive intraperitoneal injections at intervals of $48 \mathrm{~h}$ at a dose of $100 \mathrm{mg} / \mathrm{kg}$ body weight (total dose of $300 \mathrm{mg} / \mathrm{kg}$ 
weight) (see Fig. 3 for detailed protocol). Prior to injection, ALX was dissolved in $0.05 \mathrm{M}$ citrate buffer at $\mathrm{pH} 4.0$ because of instability at neutral $\mathrm{pH}$. The control group given UPW was injected with the citrate buffer only. MWs and UPW were given as drinking water and changed daily until the end of the study. Behavioral changes for polydipsia, polyphagia and polyuria were monitored in all mice throughout the experiment. Body weights were measured once a week at the designated time of the day. Water and food consumption were measured three times a week. Daily water and food consumption were calculated for each mouse by combining the total weight of the water consumed and food consumption every 2 day period.

The present report is a part of an original investigation, which used both MWs and electrochemically reduced water (ERW) as test waters. The results were reported separately because MWs are natural in origin, while ERW is artificial water. Therefore, markers and measurement scales in several figures of this manuscript are the same as those in the previous report (Li et al. 2011).

\section{Determination of blood glucose and insulin levels}

For blood glucose assay, blood samples from the treated mice were collected at weeks $0,4,6,7,8$ and 9 by puncturing a tail vein of the mice during the fasting period between 9:00 and 12:00 a.m. Blood glucose levels were determined by a glucose auto-analyzer (Bayer Corporation, Beaver Falls, PA). Mice with basal glucose levels under fasting conditions ranging between 150 and $350 \mathrm{mg} / \mathrm{dL}$ were considered mild ALX-induced diabetic mice, and higher than $350 \mathrm{mg} /$ $\mathrm{dL}$ were considered as severe ALX-induced diabetic mice (Alarcon-Aguilar et al. 2000). Blood samples for measuring serum insulin levels were obtained at the 9th week before sacrifice by the orbital sinus puncture technique using capillary glass tubes. Sera were separated by centrifugation at $805 \times g$ for $15 \mathrm{~min}$ at $4{ }^{\circ} \mathrm{C}$. Serum insulin levels were estimated by the ELISA method using an insulin assay kit (Morinaga Seikagaku Corporation, Yokohama, Japan) following the manufacturer's instructions.

Catalase and SOD activity in the serum and pancreas

To estimate catalase and SOD activity, sera were obtained via the orbital sinus puncture technique and measurements were carried out using the method described for in vitro studies. To estimate catalase and SOD activity in the pancreas, the whole pancreas was homogenized in three volumes of $50 \mathrm{mM}$ potassium phosphate buffer ( $\mathrm{pH}$ 7.0) containing $1 \mathrm{mM}$ EDTA, and centrifuged at $11,000 \times g$ for $20 \mathrm{~min}$ at $4{ }^{\circ} \mathrm{C}$. The supernatants were used for the estimation of catalase and SOD activity, as described above.

\section{Determination of mineral contents}

Mineral contents of MWs were determined by inductively coupled plasma mass spectrometry (ICP-MS, Agilent 7500, Agilent Technologies, CA, USA) at the Center for Advanced Instrumental Analysis, Kyushu University.

\section{Ethical committee approval}

This experiment was carried out under the guidance for Animal Experiments in the Faculty of Agriculture and in the Graduate School of Kyushu University and the Law (No.105) and Notification (No.6) of the Government.

\section{Statistical analysis}

For statistical analysis, the Tukey-Kramer method was used except for the analysis of body weight to determine the levels of significance between the means of control and experimental values. Statistical analysis for body weight was performed using the least significant difference method. Statistical analysis of Ryan's method was applied to Table 1. Results are expressed as the mean \pm standard error of the mean (SEM) of independent experiments with one tail. A value of $p \leq 0.05$ was considered as statistically significant.

\section{Results}

Effect of NRWs on alloxan-induced apoptosis of HIT-T15 cells

To visualize the protective effect of NRWs, low molecular weight DNAs were selectively isolated from HIT-T15 cells treated with NRWs and/or ALX. The DNA pattern obtained from the cells treated with 
Table 1 Anti-diabetic effects of four waters on alloxan treated male ICR mice

\begin{tabular}{|c|c|c|c|c|c|c|c|c|c|c|}
\hline \multirow{3}{*}{$\begin{array}{l}\text { Water after ALX injection } \\
\text { B. G. L. (mg/dL) }\end{array}$} & \multicolumn{9}{|c|}{ No. of diabetic mice and of death } & \multirow{3}{*}{$\begin{array}{l}\text { Reduction rate } \\
\text { 9th weeek } \\
>150\end{array}$} \\
\hline & \multicolumn{3}{|l|}{ 6th week } & \multicolumn{3}{|l|}{ 7th week } & \multicolumn{3}{|c|}{ 9th weeek } & \\
\hline & $150-350$ & $>350$ & Death & $150-350$ & $>350$ & Death & $150-350$ & $>350$ & Death & \\
\hline UPW (n = 12) & 2 & 4 & 1 & 5 & 5 & 2 & 2 & 7 & 3 & $100 \%$ \\
\hline Hita T. W. $(n=12)$ & 8 & 0 & 0 & 9 & 2 & 0 & 6 & 3 & 0 & $75.0 \%$ \\
\hline Nord. W. $(\mathrm{n}=12)$ & 3 & 0 & 0 & 5 & 2 & 0 & 6 & 2 & 0 & $66.7 \%$ \\
\hline CNMW (n = 12) & 4 & 2 & 1 & 3 & 6 & 1 & 4 & 5 & 2 & $90.0 \%$ \\
\hline
\end{tabular}

CD-1 strain of male ICR mice were administrated four types of water for 9 weeks. ALX injections and blood sampling for B.G.A. were carried out as detailed in the study protocol (Fig. 3). Presented data are the numbers of mice categorized into two hyperglycemic levels (mild diabetes: $150-350 \mathrm{mg} / \mathrm{dL}$ and severe diabetes: $>350 \mathrm{mg} / \mathrm{dL}$ ) and of dead mice observed in the 6th, 7th, and 9th week after ALX injection. Percent reductions of diabetes development exhibiting blood glucose levels of greater than $150 \mathrm{mg} / \mathrm{mL}$ were calculated at the end of the 9th week. UPW (Control): ultra pure water; Hita T. W.: Hita tenryosui water; Nord. W.: Nordenau water, CNMW: a commercialized brand, B.G.L: blood glucose level (mg/dL)

UPW alone showed one band near to the gel origin (Fig. 1a, UPW(-)ALX), while the cells incubated with ALX containing UPW showed a ladder pattern ranging from high to low molecular weight bands with clustered bands at approximately 200 b.p., and the band near the gel well completely disappeared (Fig. 1a, UPW(+)ALX). However, a discrete band closer to the gel well remained when the cells were pretreated with Hita T. W. or Nord. W.-based medium prior to ALX treatment (Fig. 1a, Hita T. W.(+)ALX and Nord $\mathrm{W}(+) \mathrm{ALX})$. The DNA pattern obtained from the cells pretreated with CNMW-based medium followed by ALX treatment showed a ladder pattern ranging from high to low molecular weight bands (Fig. 1a, CNMW(+)ALX). These results demonstrated that MWs, except for CNMW and UPW (control), prevented DNA degradation caused by ALX. Additionally, we found that Hita T. W. and Nord. W. greatly suppressed DNA fragmentation compared with that of CNMW by using DNA fragmentation ELISA kit (data not shown).

To further confirm the effects of NRWs, we performed a TUNEL assay. UPW containing ALXbased medium significantly increased TUNEL positive cells to $66.93 \pm 2.94 \%$ compared with $5.16 \pm 0.44 \%$ in HIT-T15 cells cultured in UPWbased medium alone (Fig. 1b, $p<0.001$ ). However, when HIT-T15 cells were pretreated with Hita T. W. and Nord. W., TUNEL positive cells were significantly reduced to $34.90 \pm 1.82 \%$ (Fig. $1 b$, cf. UPW(+)ALX vs. Hita T. W.(+)ALX; $p<0.001)$ and $51.87 \pm 0.85 \%$ (Fig. 1b, cf. UPW(+)ALX vs.
Nord. W.(+)ALX; $p<0.001)$, respectively. In contrast, CNMW increased TUNEL positive cells to $75.77 \pm 1.46 \% \quad$ (Fig. 1b, cf. UPW(-)ALX vs. CNMW(+)ALX; $p<0.001)$. Although Hita T. W. and Nord. W. reduced the percentage of TUNEL positive cells, levels were still higher compared with those of controls (Fig. 1b, cf. UPW(-)ALX vs. Hita T. W. (+)ALX or Nord. W. (+)ALX; $p<0.001)$ suggesting that ALX irreversibly damages cells to a certain extent.

Apoptotic cells showed a decreased DNA content compared with that of the $G_{0} / G_{1}$ level. Therefore, to quantitate apoptotic cells, flow cytometric analysis was applied to PI-stained DNA obtained from the cells treated with ALX for $4 \mathrm{~h}$ (Fig. 1c). The distribution of the cell cycle phase in HIT-T15 cells cultured in medium containing the various waters was examined after exposure to ALX. The population of cells in the sub- $\mathrm{G}_{1}$ phase increased to levels as high as $39.5 \%$ after exposure to ALX for $4 \mathrm{~h}$ (Fig. 1c), while that of cells treated with UPW alone as a control was $4.7 \%$ (Fig. 1c). However, HIT-T15 cells pretreated with Hita T. W. and Nord. W.-based medium prior to ALX addition restored the sub- $\mathrm{G}_{1}$ phase to 8.5 and $11.8 \%$ (Fig. 1c), respectively. The same treatment with CNMW increased the sub- $\mathrm{G}_{1}$ phase to $40.4 \%$ (Fig. 1c). Therefore, sub- $\mathrm{G}_{1}$ analysis clearly demonstrated that Hita T. W. and Nord. W. prevent ALX induced apoptosis in HIT-T15 cells. The results of three independent assays consistently demonstrated that Hita T. W. and Nord. W. effectively prevents ALX-induced apoptotic cell death (Fig. 1a-c). 

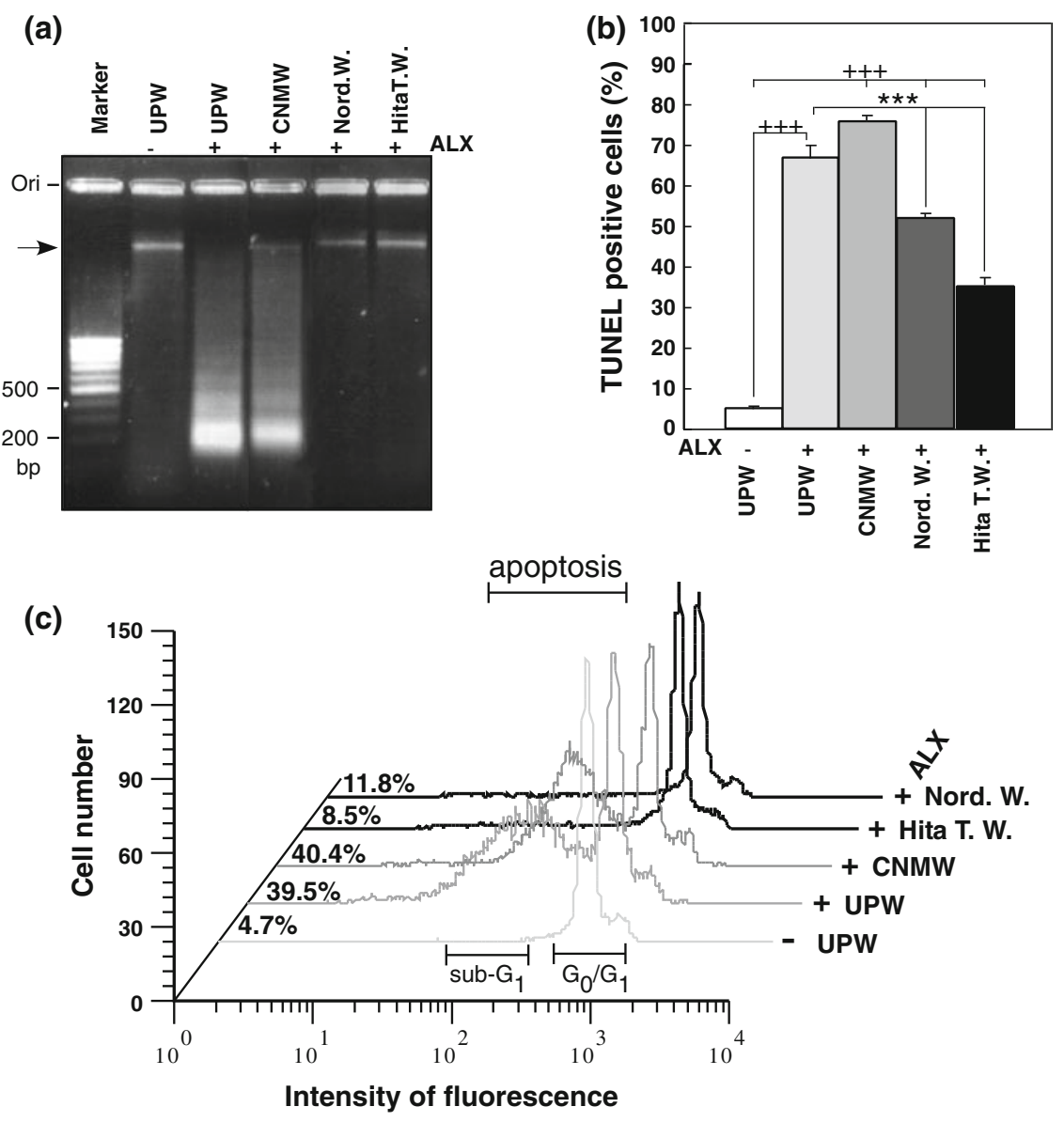

Fig. 1 Anti-apoptotic effects of various waters on alloxan-treated HIT-T15 cells. Anti-apoptotic effects were assessed by DNA fragmentation analysis (a), TUNEL assay (b), and sub- $\mathrm{G}_{1}$ analysis (c). HIT-T15 cells were pre-incubated with various waters for $24 \mathrm{~h}$, and then treated with $1 \mathrm{mM}$ alloxan for $4 \mathrm{~h}$. a The amount of fragmented DNA was measured. DNA was isolated and electrophoresed as described in the "Materials and methods". The gels were stained with ethidium bromide and photographed under ultraviolet light. Similar results were obtained in three independent experiments, and a representative experiment is presented. "Marker lane" indicates a molecular weight marker (100 b.p. DNA ladder). Group designations are as follows: UPW(-) indicates ultrapure water (UPW) without alloxan; UPW(+)ALX indicates UPW plus $1 \mathrm{mM}$ alloxan; CNMW(+)ALX indicates a brand of commercialized natural mineral water plus $1 \mathrm{mM}$ alloxan; Nord. W.(+)ALX indicates Nordenau water plus $1 \mathrm{mM}$ alloxan; Hita T. W.(+)ALX indicates Hita Tenryosui water plus $1 \mathrm{mM}$ alloxan. b Antiapoptotic effects of various waters on alloxan-treated HIT-T15

Effect of NRWs on the activity of anti-oxidative enzymes in HIT-T15 cells

To assess if NRWs affect the activity of anti-oxidative enzymes, SOD and catalase activities were measured in cells. Cells were pre-incubated with various waters for $24 \mathrm{~h}$ followed by $1 \mathrm{mM}$ alloxan treatment for $4 \mathrm{~h}$. Apoptotic cells were detected by the TUNEL procedure and analyzed by flow cytometry. Values represent the means \pm standard error of the mean of three independent experiments. ${ }^{+++} p<0.001, \mathrm{UPW}(-)$ compared with various waters with $1 \mathrm{mM}$ alloxan; ***p $<0.001$, UPW(+) compared with Hita T. W.(+)ALX or Nord. W.(+)ALX. Group designations are the same as those in a. $\mathbf{c}$ Effect of various waters on changes of sub- $\mathrm{G}_{1}$ content in alloxan-treated HIT-T15 cells. HITT15 cells seeded on $60 \mathrm{~mm}$ dishes were cultured in HBSS buffer with or without $1 \mathrm{mM}$ alloxan for $4 \mathrm{~h}$. Cells were stained with propidium iodide and subjected to flow cytometric analysis for the measurement of the sub- $G_{1}$ phase. Cells undergoing apoptosis contain a reduced amount of DNA compared with that of cells in the $\mathrm{G}_{1}$ phase and they exhibit an additional peak at the left side of the $\mathrm{G}_{1} / \mathrm{G}_{0}$ peak position as indicated as apoptosis $\left(\mathrm{sub}-\mathrm{G}_{1}\right)$ in the panel. Sub-diploid apoptotic cells (sub- $\mathrm{G}_{1}$ ) are expressed as a percentage on the left side of each profile

the supernatant prepared from HIT-T15 cells cultured in UPW or various water-based media with or without ALX (Fig. 2). Control SOD activity was $100 \pm 6.6 \%$ using cells cultured in UPW-based medium without ALX (Fig. 2a). When ALX was added to UPW-based 
control medium, SOD activity was significantly suppressed to $84.36 \pm 3.6 \%$ (Fig. $2 \mathrm{a}, p<0.05$ ). The SOD activity of cells cultured with Hita T. W.-based medium with ALX was decreased to $83.6 \pm 2.2 \%$ (Fig. 2a, $p<0.05)$ and that of cells cultured with CNMW-based medium with ALX was drastically decreased to $63.19 \pm 4.9 \%$ compared with UPW-based control medium (Fig. 2a, $p<0.001$ ). The SOD activity of cells cultured with Nord. W.-based medium with ALX was restored to $88.90 \pm 1.5 \%$ compared with the UPWbased control medium (Fig. 2a, $p<0.05$ ).

Control catalase activity was determined to be $100 \pm 3.7 \%$ using cells cultured in UPW-based medium without ALX (Fig. 2b). When ALX was added to UPW-based medium, catalase activity was decreased to $80.36 \pm 0.7 \%$ (Fig. $2 b, p<0.001$ ). Catalase activity in supernatant prepared from HITT15 cells cultured in Hita T. W.- or CNMW-based medium with ALX was further suppressed to $68.19 \pm 5.1 \%$ and $52.91 \pm 9.1 \%$, respectively, compared with UPW-based medium with ALX(Fig. 2b, $p<0.001)$. Surprisingly, catalase activity in supernatant prepared from cells cultured in Nord. W. with ALX was significantly elevated to $114.25 \pm 13.1 \%$ compared with UPW-based medium with ALX (Fig. 2b, $p<0.001$ ). The present results demonstrated that Nord. W. reversed ALX-induced anti-oxidative enzyme suppression in vitro.

Incidence of diabetes in $\mathrm{CD}-1$ mice treated with ALX and various waters

Using the pancreatic $\beta$-cell line, HIT-T15 cells, we had already shown that NRWs possess anti-apoptotic effects. These results suggested the possibility that these NRWs could exert a similar effect in vivo. To investigate this possibility, we designed an in vivo study protocol (Fig. 3). As shown in Table 1, diabetes was induced in all the mice $(100 \%)$ pretreated with UPW prior to ALX-injections in 2 weeks (i.e., the 7th week from day 0; UPW: control). This control experiment showed that the study protocol was effective in inducing diabetes, although $25 \%$ died within 4 weeks (i.e., the 9th week from day 0, Table 1) after ALX treatment. The incidence of diabetes development for mice treated with Hita T. W. and Nord. W. was reduced to 75 and $66.7 \%$, respectively, but CNMW reduced it to $90.0 \%$. Statistical analysis on reduction rates of DM development did not reveal significant difference
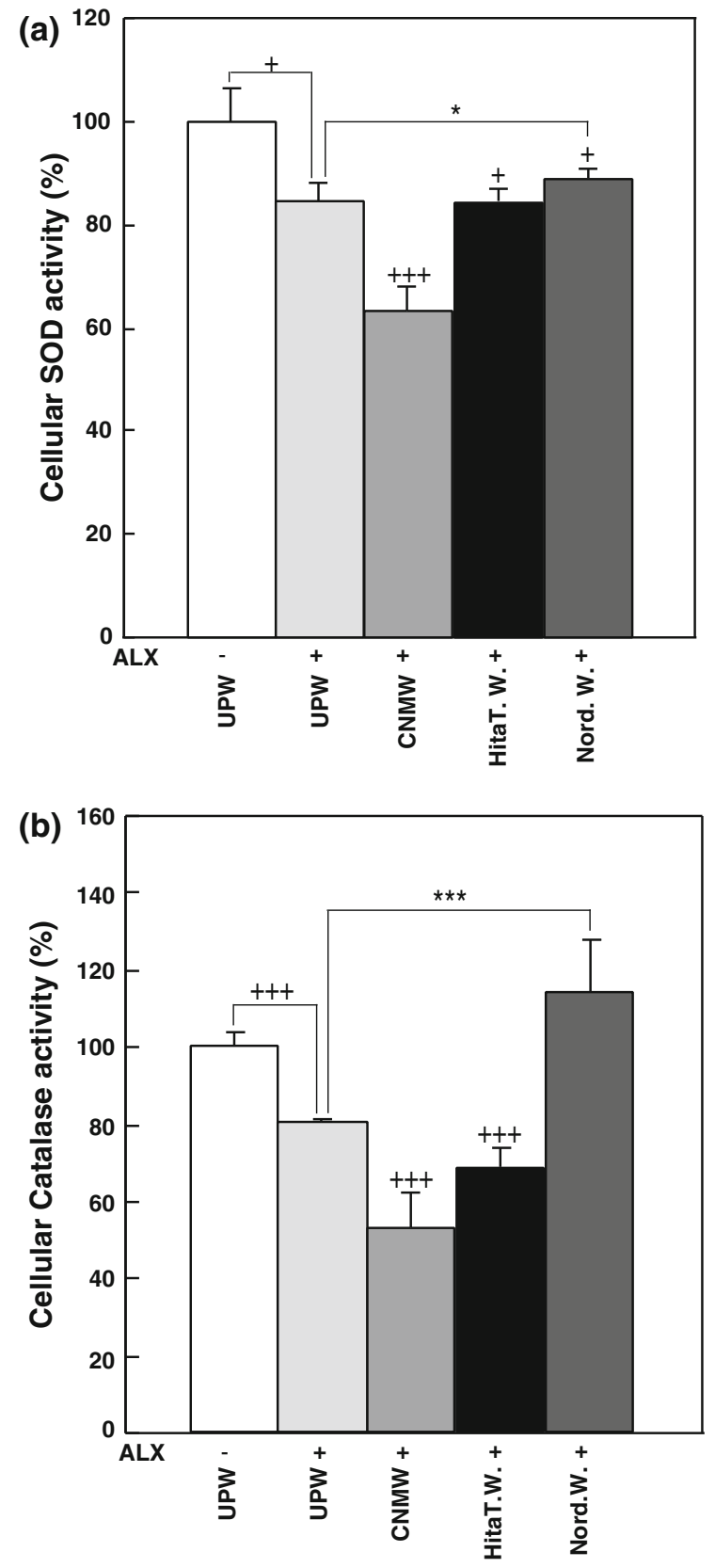

Fig. 2 Effect of NRWs on cellular SOD and catalase production in alloxan-treated HIT-T15 cells. HIT-T15 cells were pretreated with various waters for $24 \mathrm{~h}$ prior to $4 \mathrm{~h}$ treatment with $1 \mathrm{mM}$ alloxan. Cells were harvested and processed for SOD activity (a) and catalase activity (b) as described in the "Materials and methods" section. Values represent the means \pm standard error of the mean of three independent experiments. ${ }^{+} p<0.05,{ }^{+++} p<0.001$, UPW(-) compared with various waters with alloxan treatment; $* p<0.05$, $* * * p<0.001$, UPW(+)ALX compared with Hita T. W.(+)ALX or Nord. W.(+)ALX. Group designations are the same as those in Fig. 1a 
between UPW and Hita T.W. or Nord. W. $(p>0.05)$. Notably, three mice administered Hita T. W. and four mice administered Nord. W. survived with normoglycemic levels of less than $150 \mathrm{mg} / \mathrm{dL}$. Therefore, Hita T. W. and Nord. W. partly protected animals from developing ALX-induced T1DM.

Effect of NRWs on serum insulin levels

in the ALX-induced model of diabetes in mice

Serum insulin level is an important marker to monitor pancreatic function, and can be used to evaluate the extent of tissue damage and physiological vitality. Blood samples were collected at the 9th week for serum insulin quantitation. The insulin level of mice given UPW only was $1,391.5 \pm 325 \mathrm{pg} / \mathrm{mL}$ (Fig. 4). When mice were given UPW and then administered ALX, the serum insulin level was significantly suppressed to $47.5 \pm 7.7 \mathrm{pg} / \mathrm{mL}$ compared with UPW alone (Fig. 4, $p<0.001)$. However, serum insulin levels were significantly elevated to $166.5 \pm 10.0 \mathrm{pg} / \mathrm{mL}$ in mice administered Hita T. W. with ALX $(p<0.01)$ and $155.5 \pm$ $5.4 \mathrm{pg} / \mathrm{mL}$ in mice administered Nord. W. and ALX $(p<0.01)$ compared with those in UPW and ALXtreated mice (Fig. 4). On the other hand, insulin levels were slightly improved by CNMW, although this was not significant (Fig. 4). Therefore, Hita T. W. and Nord. $\mathrm{W}$. were found to have positive and/or preventive effects against ALX-induced insulin suppression.

Effect of NRWs on blood glucose levels in the ALX-induced model of diabetes in mice

To evaluate the diabetic condition of mice, blood glucose levels were measured using sera obtained at 0 ,

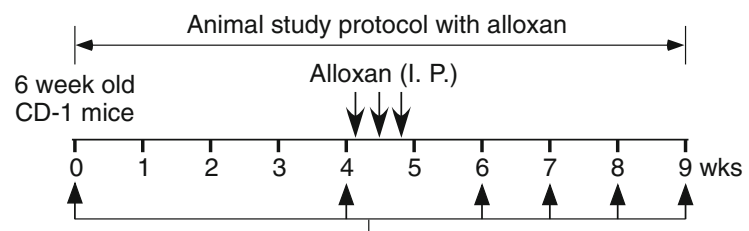

Blood samplings for Blood Glucose Assay (B.G.A.)

Adapted from Li et al. (2011)

Fig. 3 Schematic representation of the in vivo study protocol with alloxan and various waters. Six-week-old CD-1 mice were treated with various waters for up to 9 weeks. Alloxan was administered intraperitoneally (I.P.) at the indicated time points ( $\downarrow$ ). Blood samples were taken at the indicated time points and used for blood glucose assay (indicated by $\uparrow$ ). Adapted from Li et al. (2011)
4 and 8 weeks. The group of mice given UPW for 8 weeks maintained blood glucose levels of $97.33 \pm 9.63 \mathrm{mg} / \mathrm{dL}$, and this value was designated as the control value (Fig. 5). Blood glucose levels at 0 and 4 weeks were similar to those of control levels (8 weeks). Administration of ALX significantly elevated blood glucose levels to $569.33 \pm 49.33 \mathrm{mg} / \mathrm{dL}$ (Fig. 5, $p<$ 0.001 ) indicating that the study protocol was effective in inducing hyperglycemic conditions. Blood glucose levels of ALX-injected mice given UPW, Hita T. W., Nord. W. and CNMW for 8 weeks were significantly increased to $569.33 \pm 49.33 \mathrm{mg} / \mathrm{dL} \quad(p<0.001), \quad 342.50 \pm 92.14$ $\mathrm{mg} / \mathrm{dL}(p<0.01), 366.00 \pm 91.82 \mathrm{mg} / \mathrm{dL}(p<0.01)$, and $544.50 \pm 81.21 \mathrm{mg} / \mathrm{dL}(p<0.001)$, respectively, compared with basal levels $(97.33 \pm 9.63 \mathrm{mg} / \mathrm{dL}$, Fig. 5). However, blood glucose levels in Hita T. W. and Nord. W. given to ALX-injected mice were significantly lower than those in UPW given to ALX-injected mice (both $p<0.01$ ). When ALX-injected mice were given CNMW, blood glucose levels were slightly lower

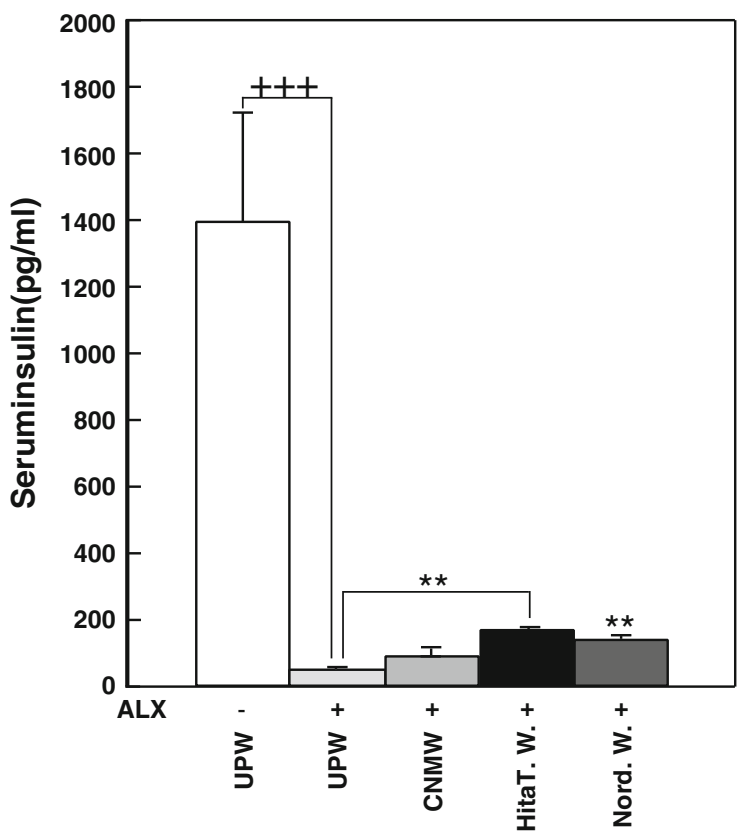

Fig. 4 The effect of natural mineral waters on serum insulin levels of alloxan-administered CD-1 mice. Blood samples were collected via orbital sinus puncture technique at the 9th week. Values are means \pm standard error of the mean $(n=8)$. ${ }^{* *} p<0.01$, mice administered ultrapure water compared with those given natural mineral water followed by alloxan administration. Group designations are the same as those in Fig. 1a 
$(544.50 \pm 81.21 \mathrm{mg} / \mathrm{dL})$ compared with those in UPW ALX-injected mice, but this was not significant (Fig. 5). Taken together, these results showed that Hita T. W. and Nord. W. had hypoglycemic effects. Although the reduction in blood glucose levels by NRWs was effective, mice were considered to be mildly diabetic, which suggested that the hypoglycemic effect of NRWs was mild.

Effect of NRWs on the activity of anti-oxidative enzymes in pancreatic tissue

SOD activity determined in pancreatic tissue of mice given UPW alone was designated as the control (Fig. 6a, $100 \pm 10.13 \%$ ). When ALX was administered to mice given UPW, SOD activity was significantly reduced to $57.89 \pm 21.39 \%$, and this value was designated as a second control (Fig. 6a, $p<$ 0.05). SOD activity in pancreatic tissue obtained from mice administered Hita T. W. and Nord. W. with ALX recovered to $91.45 \pm 8.42$ and $97.93 \pm 5.45 \%$, respectively, and this activity was significantly higher than that in UPW and ALX-treated mice (Fig. 6a, $p<0.05$ ). SOD activity of mice given CNMW and thenALX was significantly reduced to $78.63 \pm 6.62 \%$ compared with that for UPW alone (Fig. 6a, $p<0.05$ ) indicating that CNMW could not restore SOD activity. Catalase activity determined in pancreatic tissue of mice given UPW only was used as a control (Fig. 6b, $100 \pm 30.93 \%$ ). Catalase activity in pancreatic tissue obtained from mice given UPW and treated with ALX was included as a second control and the results showed that catalase activity was significantly reduced to $73.39 \pm 20.21 \%$ compared with activity in mice given UPW alone (Fig. 6b, $p<0.05$ ). When mice were given Nord. W. and later treated with ALX, catalase activity in pancreatic tissue was significantly increased to $101.74 \pm 16.35 \%$ compared with that in mice given UPW and ALX (Fig. 6b, $p<0.05$ ). However, catalase activity in pancreatic tissue obtained from mice administered Hita T. W. or CNMW followed by ALX administration was significantly decreased $(81.56 \pm 8.09 \%$ and $71.19 \pm$ $20.48 \%$, respectively) compared with that in mice given UPW alone (Fig. 6b, $p<0.05$ ). Although catalase and SOD activities in serum were also measured, there were no significant differences between controls and NRWs (data not shown).

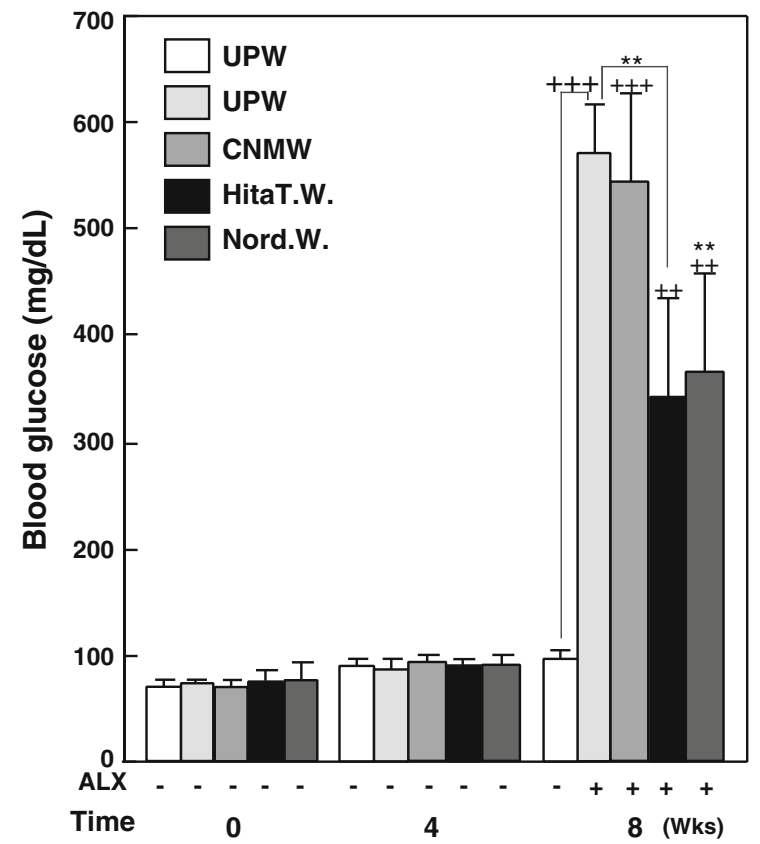

Fig. 5 The effect of various waters on blood glucose levels of normal and diabetic CD-1 mice induced by alloxan. CD-1 mice were treated as described in the study protocol (Fig. 3). Each value denotes the mean \pm standard error of the mean $(n=8)$. ${ }^{++} p<0.01,{ }^{+++} p<0.001$, control (ultrapure water without alloxan) compared with various waters with alloxan. ${ }^{* *} p<0.01$, ultrapure water with alloxan compared with various waters with alloxan. Group designations are the same as those in Fig. 1a

Effect of NRWs on body weight, food and water consumption

Body weight was monitored for each mouse at 0,4 and 8 weeks (Fig. 7a). Control mice (UPW alone) reached $40.88 \pm 2.46 \mathrm{~g}$ and maintained their body weight throughout the experimental period while that of ALX-injected mice varied between $36.45 \pm 1.16$ and $38.20 \pm 1.07 \mathrm{~g}$ (Fig. 7a, 8th week). In ALX-induced diabetic mice, the groups administered Hita T. W. and Nord. W. showed significantly restored body weights at the 8th week (Fig. 7a, cf. UPW(+)ALX [36.45 \pm $1.16 \mathrm{~g}$ ] vs. Hita T. W. [38.02 $\pm 0.54 \mathrm{~g}, p<0.05]$ and Nord. W. [38.20 $\pm 1.07 \mathrm{~g}, p<0.05])$. However, the body weight of mice given CNMW remained at a level $(36.58 \pm 0.67 \mathrm{~g})$ similar to that of UPW with ALX treatment (Fig. 7a).

Daily food consumption of mice given UPW $(p<0.05)$ and CNMW $(p<0.05)$ was notably 

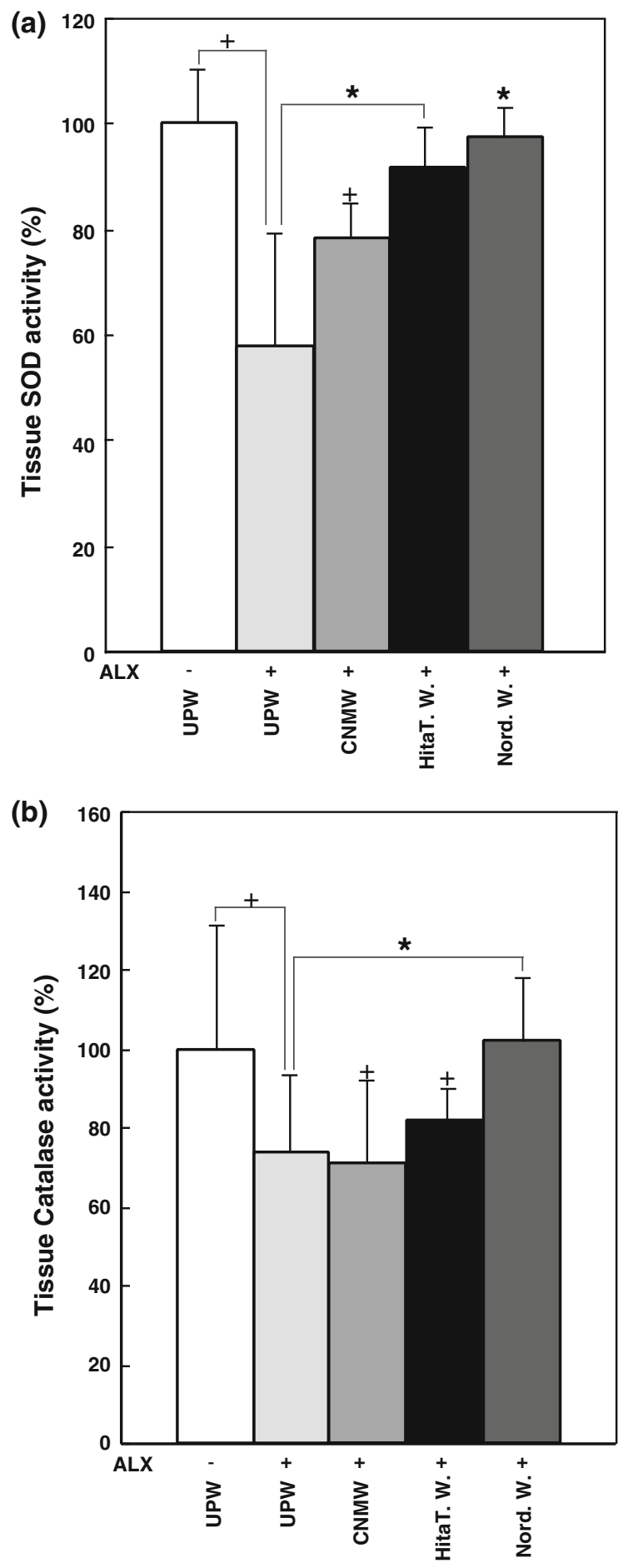

decreased by the 5th week at the end of the ALXtreatment period compared with that in Nord. W. mice, and then it was increased by approximately twofold within 1 week, followed by a gradual increase toward
Fig. 6 Effect of natural mineral waters on superoxide dismutase and catalase production in tissue isolated from alloxantreated mice. a, b Mice were pretreated with various waters followed by alloxan injection. Nine weeks later, the pancreas was excised from mice for enzyme activity measurements. Values represent the means \pm standard error of the mean of three independent experiments. ${ }^{+} p<0.05$, UPW(-)ALX compared with various waters with alloxan treatment; $* p<0.05$, UPW(+)ALX compared with Hita T. W. (+)ALX or Nord. W.(+)ALX. Group designations are the same as those in Fig. 1a

the end of the study (Fig. 7b). Daily food consumption of Nord. W.-administered mice ceased to increase after the 7th week and then it declined, while UPWadministered mice showed a gradual increase (Fig. 7b). At the 9th week, food consumption of mice administered Hita T. W. $(p<0.001)$, Nord. W. $(p<0.01)$ or CNMW $(p<0.01)$ was significantly decreased compared with that in mice given UPW with ALX (Fig. 7b).

Trends in daily water consumption of the five groups were similar to those of food consumption without a decline in consumption at the end of the 5th week (Fig. 7c). However, water consumption of mice administered Nord. W. declined after the 7th week, similar to food consumption (Fig. 7b and c). Among the ALX-treated groups, mice administered Hita T. W. (6th week: $p<0.01 ; 7$ th, 8th and 9th weeks: $p<0.001$ ), Nord. W. (6th week: $p<0.05$; 7th week: $p<0.01$; 8th and 9th weeks: $p<0.001)$ and CNMW (6th week: $p<0.05$; 7th week: $p<0.001$; 9 th week: $p<0.001$ ) had significantly reduced water consumption levels compared with those in mice given UPW. This suggested that mice given UPW with ALX consumed the most water, which reflects the severity of the hyperglycemic condition. Furthermore, mice administered Hita T. W. (8th week: $p<0.01$; 9th week: $p<0.05$ ) and Nord. W. (8th week: $p<0.05$ ) had significantly reduced water consumption levels compared with those in mice given CNMW, which indicated an anti-hyperglycemic effect (Fig. 7c). Notably, mice given UPW alone had fairly constant water and food consumption throughout the experimental period, which was indicative of appropriate experimental conditions (Fig. 7b, c).

Mineral component analysis of MWs

NRWs were found to possess a ROS scavenging antidiabetic effect in experimental mice. The mineral 

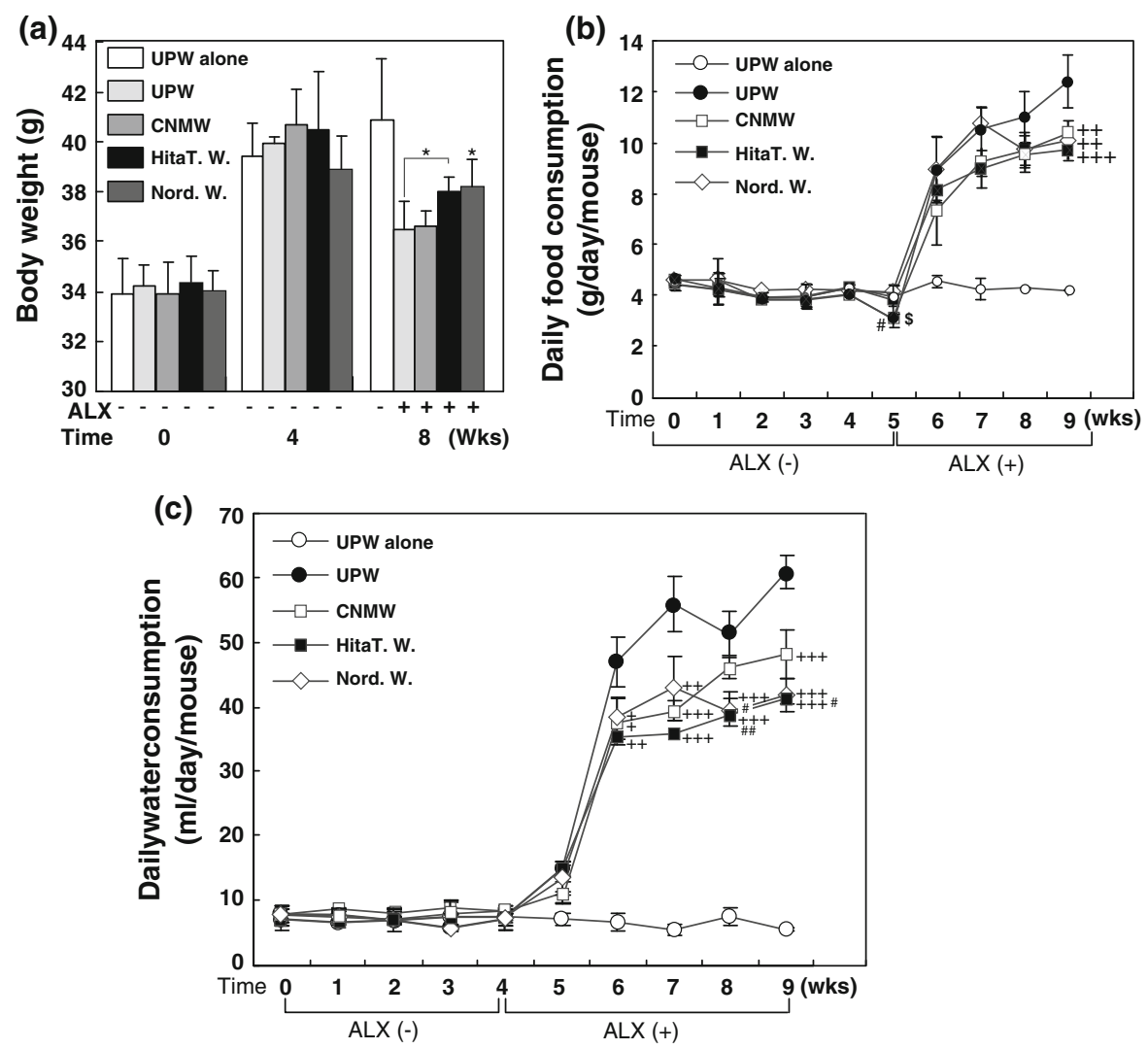

Fig. 7 The effect of various waters with or without alloxan on body weight (a), and food (b) and water (c) consumption. a Body weight was measured at the time of experimental initiation (designated as 0 weeks), and at the 4th and 8th weeks. Body weight was compared between alloxan-treated and nontreated mice. Values are means \pm standard error of the mean calculated from the data of mice that survived. ${ }^{*} p<0.05$, UPW(+)ALX compared with Hita T. W.(+)ALX or Nord. W. (+)ALX. For food and water consumption measurements, one group was placed in three cages in which three mice were placed in each cage. Consumed food and water were measured as the total weight per cage. The time course of food (b) consumption in normal and alloxan-injected mice was measured at the indicated time points ( $0-9$ weeks). Food consumption is expressed as means \pm standard error of the mean $(\mathrm{n}=3) .{ }^{++} p<0.01,{ }^{+++} p<0.001, \quad \mathrm{UPW}(+)$ ALX

content of MWs was analyzed, and the top 15 minerals contained in Hita T. W. are presented in Table 2. The mineral contents of Nord. W. and CNMW are also included for comparison. Mineral levels were variable among the waters used in this study. Nine out of 15 minerals in Hita T. W had higher levels than those of Nord. W. (H/N in Table 2). Ten of 15 minerals in Hita T. W. had higher levels than those of CNMW (H/C in Table 2). Likewise, the levels of six out of 15 minerals compared with various waters with alloxan injection. ${ }^{\#} p<0.05$, Nord. W.(+)ALX compared with CNMW(+)ALX. ${ }^{\$} p<0.05$, Nord. W.(+)ALX compared with UPW(+)ALX. Group designations are as follows: open circle ultrapure water (UPW) without alloxan; closed circle UPW plus $1 \mathrm{mM}$ alloxan; open square a brand of commercialized natural mineral water plus $1 \mathrm{mM}$ alloxan; open diamond Nordenau water plus $1 \mathrm{mM}$ alloxan; closed square Hita Tenryosui water plus $1 \mathrm{mM}$ alloxan. The time course of water (c) consumption in normal and alloxan-injected mice was measured at the indicated time points. Water consumption is expressed as means \pm standard error of the mean $(\mathrm{n}=3) .{ }^{++} p<0.01,{ }^{+++} p<0.001$, UPW(ALX) compared with various waters with alloxan injection. ${ }^{*} p<0.05$, ${ }^{\# \#} p<0.01$, CNMW(+)ALX compared with Nord. W.(+)ALX or Hita T. W.(+)ALX. Group designations are the same as those in $\mathbf{b}$

in Nord. W. were higher than those of CNMW (H/C in Table 2).

\section{Discussion}

The present study demonstrated that Hita T. W. and Nord. W. prevent HIT-T15 cell apoptosis caused by ALX-induced ROS. Li et al. reported results similar to 
Table 2 Component analysis of mineral waters

\begin{tabular}{|c|c|c|c|c|c|c|}
\hline & Hita T. W. (mg/L) & Nord. W. (mg/L) & $\mathrm{CNMW}^{*}(\mathrm{mg} / \mathrm{L})$ & $\mathrm{H} / \mathrm{N}$ & $\mathrm{H} / \mathrm{C}$ & $\mathrm{N} / \mathrm{C}$ \\
\hline $\mathrm{HCO}_{3}{ }^{-}$ & $85.600 \mathrm{mg} / \mathrm{L}$ & $122.200 \mathrm{mg} / \mathrm{L}$ & $41.600 \mathrm{mg} / \mathrm{L}$ & 0.700 & 2.06 & 2.94 \\
\hline Dis $\mathrm{Si}$ & 81.000 & 6.000 & 66.000 & 13.500 & 1.23 & 0.09 \\
\hline $\mathrm{Ca}+\mathrm{Mg}$ & 27.500 & 159.300 & 53.300 & 0.173 & 0.52 & 2.99 \\
\hline $\mathrm{Ca}$ & 9.200 & 50.000 & 13.000 & 0.184 & 0.71 & 3.85 \\
\hline $\mathrm{Na}$ & 22.100 & 3.700 & 49.100 & 5.973 & 0.45 & 0.08 \\
\hline \multirow[t]{2}{*}{$\mathrm{K}$} & 2.700 & 0.200 & 0.600 & 13.500 & 4.50 & 0.33 \\
\hline & Hita T. W. $(\mu \mathrm{g} / \mathrm{L})$ & Nord. W. $(\mu \mathrm{g} / \mathrm{L})$ & $\mathrm{CNMW}^{*}(\mu \mathrm{g} / \mathrm{L})$ & $\mathrm{H} / \mathrm{N}$ & $\mathrm{H} / \mathrm{C}$ & $\mathrm{N} / \mathrm{C}$ \\
\hline B \& B-cpd & $130.000 \mu \mathrm{g} / \mathrm{L}$ & $7.700 \mu \mathrm{g} / \mathrm{L}$ & $103.200 \mu \mathrm{g} / \mathrm{L}$ & 16.883 & 1.26 & 0.07 \\
\hline F \& F-cpd & 90.800 & 24.900 & 127.000 & 3.647 & 0.71 & 0.20 \\
\hline $\mathrm{Sr}$ & 35.980 & 166.760 & 10.640 & 0.216 & 3.38 & 15.67 \\
\hline $\mathrm{Ba}$ & 14.620 & 27.960 & 1.110 & 0.523 & 13.17 & 25.19 \\
\hline $\mathrm{Li}$ & 12.630 & 5.090 & 3.960 & 2.481 & 3.19 & 1.29 \\
\hline $\mathrm{Rb}$ & 6.480 & 0.240 & 2.970 & 27.000 & 2.18 & 0.08 \\
\hline $\mathrm{Sc}$ & 0.720 & 0.050 & 0.200 & 14.400 & 3.60 & 0.25 \\
\hline $\mathrm{Zn} \& \mathrm{Zn}-\mathrm{cpd}$ & 0.480 & 2.800 & 4.200 & 0.171 & 0.11 & 0.67 \\
\hline V & 0.390 & 0.001 & 0.100 & 390.000 & 3.90 & 0.01 \\
\hline
\end{tabular}

* CNMW a commercialized brand; cpd, compounds; Dis Si, dissolved Si; Hita T. W., Hita tenryosui water; Nord. W., Nordenau water; H/N, ratio between Hita T. W. and Nord. W.; H/C, ratio between Hita T. W. and CNMW; N/C, ratio between Nord. W. and CNMW

our study, and suggested that this protective effect could be applicable to in vivo T1DM (Li et al. 2002). The present in vivo study demonstrated that these waters affect anti-oxidative enzyme levels in cells and tissues. Additionally, serum insulin levels recovered to significantly higher levels compared with UPW and ALX-treated mice and accompanied by reduced serum glucose levels compared with those before ALX.

T1DM is characterized by insulin deficiency due to $\beta$-cell loss caused by ROS, nitric oxide and other agents (Cnop et al. 2005). ALX is known as a diabetogenic compound because it induces T1DM in vivo by generating ROS and selectively damaging pancreatic $\beta$-cells (Lenzen 2008). To maximize ALX effect, ALX was dissolved in $0.05 \mathrm{M}$ citrate buffer at $\mathrm{pH} 4.0$ immediately before use in the present study because half-life of alloxan is approximately $1.5 \mathrm{~min}$ at $37{ }^{\circ} \mathrm{C}$ at neutral $\mathrm{pH}$ (Lenzen and Munday 1991). Dissolved alloxan was added to each mineral water. Also, alloxan is known as a hydrophilic and chemically unstable molecule. Under physiological condition, alloxan is readily reduced to dialuric acid in the presence of reducing agents (Szkudelski 2001). When dialuric acid is formed, it is spontaneously autooxidized back to alloxan in the presence of oxygen which initiate a redox cycling between these two species (Elsner et al. 2006). During this redox-cycling process, cytotoxic reactive oxygen species (ROS) is generated in the absence of thiol (Elsner et al. 2006). Molecular structure of alloxan is similar to that of the glucose enabling it to be taken up by the low affinity glucose transporter GLUT2 (Elsner et al. 2002) and/or it may be taken up directly by the cells through fluid phase endocytosis (Zhang et al. 1995). Internalized alloxan is reduced to dialuric acid by intracellular reducing molecules to establish redox cycles to generate cytotoxic ROS. As a possibility, NRWs may act as a reducer for alloxan to produce dialuric acid which could initiate a redox cycle extracellularly. Initially added and redox-cycle generated alloxan molecule could be taken up into HIT-T15 cells via aforementioned routes where intracellular redoxcycling is initiated to produce ROS. Furthermore, alloxan is known to exhibit diabetogenic effect in animals when introduced by any one of administration methods; intravenously, intraperitoneally or subcutaneously. Effective dose of alloxan via intraperitoneal administration is estimated to be at least $150 \mathrm{mg} / \mathrm{kg}_{\text {b.w. }}$. in rat. Also, fasted animals are reported to be more susceptible to alloxan (Szkudelski 2001). Considering 
these, in the present study, mice were fasted for $18 \mathrm{~h}$ and administered total of $300 \mathrm{mg} / \mathrm{kg}_{\mathrm{b} \text {.w. }}$ of alloxan by three consecutive intraperitoneal injections. Injected alloxan reaches the pancreas and is preferentially taken up by $\beta$-cells through GLUT 2 transporter. Once alloxan is internalized, ROS is generated via redoxcycling to cause $\beta$-cell apoptosis and DM development. Therefore, we think that alloxan produces sufficient amount of intracellular ROS to induce both cytotoxic effect in HIT-T15 cell and T1DM effect in mouse even in the presence of NMWs. Our results support the idea that continuous supplementation of NMWs could eventually overcome the ROS generated by a limited amount of added alloxan.

Intracellular ROS levels and defending systems are delicately balanced under normal physiological conditions (Nicolls et al. 2007). However, overproduction of ROS can disturb redox homeostasis and causes accumulation of oxidative stress in cells. Such oxidative stress then contributes to $\beta$-cell apoptosis (Eizirik and Darville 2001; Cnop et al. 2005).

Previously, we reported that alloxan generated intracellular ROS particularly $\mathrm{H}_{2} \mathrm{O}_{2}$ is scavenged by Hita T. W. and Nord. W. but not by other natural mineral waters (Li et al. 2002). We monitored redox state using a combination of ROS sensitive probe, DCFH-DA, and a con-focal laser microscope or a flow cytometer. The con-focal laser microscopic analysis showed that Hita $\mathrm{T}$. W. and Nord. W. scavenged intracellular ROS as judged by color changes responding to intracellular redox states. The flow cytometric analysis also demonstrated that Hita T. W. and Nord. W. scavenged intracellular ROS at statistically significant levels compared with UPW control. Thus, ROS scavenging effect was demonstrated in both methods in the presence or absence of alloxan. Hita T. W. and Nord. W. in the absence of alloxan further reduced intracellular ROS level significantly showing further reduction of intracellular redox state from unstressed state (Li et al. 2002). Using these methods, we demonstrated that intracellular redox changes are induced by alloxan and antagonized by NMWs. Using sub- $\mathrm{G}_{1}$ assay, the present study showed anti-apoptotic effects of NMWs, previous data together with the present results link anti-apoptotic and -diabetic effect favorably to intracellular redox state modified by NMWs.

Apoptosis involves DNA fragmentations detectable as a typical DNA ladder on agarose gels. The current study demonstrated that this phenomenon occurs in
ALX-treated HIT-T15 cells and that NRWs prevent DNA fragmentation. Similar results have been reported by others and apoptotic INS-1 cell death has been linked to ALX-induced DNA fragmentation (Sakurai et al. 2001). In the apoptotic process, singlestrand nicking events undetectable by agarose gel analysis occur before DNA fragmentation. Therefore, we used the TUNEL assay enabling detection of generated single strand breaks by labeling 3 '-hydroxyl ends of nicked DNA. The TUNEL assay revealed that NRWs could reduce TUNEL positive cells indicative of reduced single-strand nicking reactions. Sub- $G_{1}$ analysis can detect apoptotic cells, and results from the current study showed positive effects of NMWs by reducing the sub- $\mathrm{G}_{1}$ population, i.e., apoptotic cells. These independent assays strongly suggest that NRWs have preventive effects against HIT-T15 cell apoptosis induced by ALX. Previous studies have shown that the overexpression of copper/zinc $(\mathrm{Cu} / \mathrm{Zn})$-superoxide dismutase and catalase provides resistance against ROS (Lortz and Tiedge 2003; Gurgul et al. 2004; Lortz et al. 2005). These reports strongly suggest that induction of anti-oxidative enzymes in pancreatic $\beta$ cells prevents diabetes development. In the present study, Hita T. W. and Nord. W. were found to increase anti-oxidative enzyme activity of SOD and catalase, although the affected enzyme activities varied between the two waters. Hita T. W. only restored tissue SOD activity, while Nord. W. restored both enzyme levels in HIT-T15 cells and pancreatic tissue. In spite of these differential effects on anti-oxidative enzymes by Hita T. W. and Nord. W., we found that mice treated with both waters exhibited significantly elevated insulin levels concurrently with a hypoglycemic effect.

We further considered about insulin levels induced by NMWs. Serum insulin level elevated by Hita T. W. is slightly higher than that by Nord. W. In support, secreted insulin level from HIT-T15 cells induced by Hita T. W. is higher than that of Nord. W. (Li et al. 2002). Sub- $G_{1}$ assay showed that anti-apoptotic effect of Hita T. W. is higher than that of Nord. W. (this study). Although ROS has been shown to attack $\beta$-cell DNA (Yamamoto et al. 1981; Takasu et al. 1991; Kaneto et al. 1996), TUNEL assay clearly showed that Hita T. W. protects from DNA strand breaks (this study). Based on these data, Hita T. W. is suggested to effectively protect DNA including insulin gene by reducing ALX-induced ROS level. Such protected insulin gene could express normally. As well, we 
reported that Hita T. W. exerts insulin mimetic action which stimulates 2-deoxy glucose uptake into L6 myotubes (Oda et al. 1999). Conversely, DNA damage activates poly (ADP-ribose) polymerase, a nuclear DNA repair enzyme, which leads to decreased cellular nicotinamide adenine dinucleotide $\left(\mathrm{NAD}^{+}\right)$and causes decreased ATP levels. Alloxan depletes cellular ATP which causes cell membrane hyper-polarization leading to voltage-dependent $\mathrm{Ca}^{2+}$ channel closure. This event induces decreased $\left[\mathrm{Ca}^{2+}\right]_{I}$ and suppression of $\mathrm{Ca}^{2+}$ oscillation and eventually results in the inhibition of insulin secretion. It was suggested that increased ATP production stimulates insulin secretion through $\mathrm{K}_{\mathrm{ATP}}^{+} /\left[\mathrm{Ca}^{2+}\right]_{I}$ channels ( $\mathrm{Li}$ et al. 2002). Previously, glucose-stimulated intracellular ATP levels were measured in alloxan treated HIT-T15 cells. Hita T. $\mathrm{W}$. was shown to elevate ATP levels 1.8-fold more than that of Nord. W. in the absence of alloxan. Also, Hita T. W. increased ATP levels 2.2-fold more than Nord. W. even in the presence of alloxan. Therefore, there is a substantial difference between Hita T. W. and Nord. $\mathrm{W}$. in terms of ATP inducibility. Indeed, glucose stimulated insulin release is in accordance with ATP levels. Hita T. W. stimulated 1.5- and 1.7-fold more insulin release than Nord. W. without and with alloxan, respectively ( $\mathrm{Li}$ et al. 2002). Serum insulin level is also higher in Hita T. W. fed mice than in Nord. W. fed mice. We suggest that although an anti-oxidative enzyme inducing ability is low, Hita T. W. could exhibit anti-T1DM effect via increasing insulin secretion and stimulating uptake of insulin at target tissues in vivo. Nord. W. may share a part of this mechanism in addition to an anti-T1DM mechanism through activation of antioxidative enzymes. It should be emphasized that the present study used NRWs as the sole source of prospective anti-diabetic agent.

The factor(s) responsible for the present antidiabetic effects in these waters is unclear. One possibility is that the anti-diabetic effector(s) may be closely linked to the mineral constituents of the NRWs. For example, certain types of mineral waters have been reported to exert anti-oxidative effects (Benedetti et al. 2009; Costantino et al. 2009). In addition, several elements such as calcium, magnesium, vanadium and silicon have been considered to be beneficial for health (Tubek 2006). In particular, magnesium, vanadium, lithium, silicon, zinc and $\mathrm{HCO}_{3}{ }^{-}$have been suggested to exert beneficial effects against DM (Soltani et al. 2005; Sales and de Fatima
Campos Pedrosa 2006; Vassort and Turan 2010). To investigate if anti-T1DM effects of NRWs could be related to minerals, we analyzed the mineral content of the MWs used in this study, and the 15 most common elements were compared among three MWs (Table 2). Our results did not show a clear difference between NRWs and CNMW. However, this finding should be interpreted with care, because in spite of the efficacy of Hunza water that has long been known for human health and longevity, its mineral content is not distinctively different from that of other waters (Keller and Feder 1979). Additionally, a positive correlation has been observed between trace elements in lotus seeds and anti-diabetic properties (Mani et al. 2010). Just recently, Kitagawa et al. reported that organic solvents extractable and freeze labile special components in Hita T. W. promote aquaporin activities. Such components moving via aquaporin are suggested to activate cellular immune responses which allow prevention and/or treatment of some chronic diseases (Kitagawa et al. 2011).

Alternatively, it is known that natural waters including ground and surface waters, treated drinking waters and different brands of mineral waters contain various nanoparticles (Wagner et al. 2004; Wigginton et al. 2007; Handy et al. 2008). Nanoparticles (fibrous polysaccharide particles and spherical organic matter) in drinking water are visualized using an atomic force microscope and transmission electron microscope. The total particle number has been estimated to be $7-10 \times 10^{8}$ particles $/ \mathrm{mL}$ in a conventionally treated drinking water (Kaegia et al. 2008). Furthermore, artificially synthesized platinum nanoparticles have been shown to exhibit ROS scavenging activity in HeLa cells (Hamasaki et al. 2008), suggesting the possibility that other nanoparticles could exert similar biological effects. Based on these reports, Hita T. W. and Nord W. are likely to contain various forms of nanoparticles enabling anti-T1DM effects.

Moreover, natural waters have been described to contain amorphous silicate minerals as a form of nanoparticles, which exert antioxidative potential by the adsorbed hydrogen anion (Kimberly et al. 2001). Subsequently, a novel silsequioxane bioencapusulated-hydride compound (named silica hydride) was synthesized and several investigations revealed that the silica hydride slowly liberates the hydride ion in an aqueous environment for several weeks, and they showed ROS scavenging activity without cytotoxicity 
(Stephanson and Flanagan 2003a, b; Stephanson and Flanagan 2004). Recently, a protective effect of silica hydride has also been described against the hepatotoxin, carbon tetrachloride $\left(\mathrm{CCl}_{4}\right)$, which induced liver damage in mice via elevating anti-oxidative enzyme levels (Hsu et al. 2010). Although further investigations are required, accumulated data suggest that Hita T. W. and Nord. W. contain nanoparticles and/or metal hydrides giving rise to anti-oxidative activity observed in the present studies. Currently, we are fractionating NMWs by molecular sizes using ROS scavenging ability as a marker to isolate substance(s) conferring the reducing and/or ROS scavenging abilities.

In conclusion, Hita T. W. and Nord. W. can prevent ALX-induced apoptosis in vitro and the effect is applicable to T1DM in experimental animals. The protective action of NRWs may be related to their ability to prevent and/or quench free radicals generated in cells and tissues, and by elevating the levels of anti-oxidant enzymes.

\section{References}

Alarcon-Aguilar FJ, Jimenez-Estrada M, Reyes-Chilpa R, Gonzalez-Paredes B, Contreras-Weber CC, Roman-Ramos R (2000) Hypoglycemic activity of root water decoction, sesquiterpenoids, and one polysaccharide fraction from Psacalium decompositum in mice. J Ethnopharmacol 69: 207-215

Benedetti S, Benvenuti F, Nappi G, Fortunati NA, Marino L, Aureli T, De Luca S, Pagliarani S, Canestrari F (2009) Antioxidative effects of sulfurous mineral water: protection against lipid and protein oxidation. Eur J Clin Nutr 63: 106-112

Bresson D, von Herrath M (2007) Moving towards efficient therapies in type 1 diabetes: To combine or not to combine? Autoimmun Rev 6:315-322

Claiborne A (1985) Catalase activity. In: Greenwald RA (ed) "CRC Handbook of Methods for Oxygen Radical Research", CRC Press, Boca Raton, pp 283-284

Cnop M, Welsh N, Jonas J-C, Jörns A, Lenzen S, Eizirik DL (2005) Mechanisms of pancreatic $\beta$-cell death in type 1 and type 2 diabetes: many differences, few similarities. Diabetes 54:s97-s107

Costantino M, Giuberti G, Caraglia M, Lombardi A, Misso G, Abbruzzese A, Ciani F, Lampa E (2009) Possible antioxidant role of SPA therapy with chlorine-sulphur -bicarbonate mineral water. Amino Acids 36:161-165

Eizirik DL, Darville MI (2001) $\beta$-cell apoptosis and defense mechanisms. Lessons from type 1 diabetes. Diabetes 50: S64-S69

Elsner M, Tiedge M, Guldbakke B, Mundy R, Lenzen S (2002) Importance of the GLUT2 glucose transporter for pancreatic beta cell toxicity of alloxan. Diabetologia 45:15421549
Elsner M, Gurgul-Convey E, Lenzen S (2006) Relative importance of cellular uptake and reactive oxygen species for the toxicity of alloxan and dialuric acid to insulin-producing cells. Free Radic Biol Med 41:825-834

Gadek Z, Li Y, Shirahata S (2006) Changes in the relevant test parameters of 320 diabetes patients under the influence of the so called 'Nordenau-phenomenon' in the prospective observation procedure. In: Iijima S, Nishijima K (eds) Animal cell technology: basic \& applied aspects, vol 14. Kluwer, The Netherlands, pp 377-385

Gurgul E, Lortz S, Tiedge M, Jörns A, Lenzen S (2004) Mitochondrial catalase overexpression protects insulin-producing cells against toxicity of reactive oxygen species and proinflammatory cytokines. Diabetes 53:2271-2280

Hamasaki T, Kashiwagi T, Imada T, Nakamichi N, Aramaki S, Toh K, Morisawa S, Shimakoshi H, Hisaeda Y, Shirahata S (2008) Kinetic analysis of superoxide anion radical-scavenging and hydroxyl radical-scavenging activities of platinum nanoparticles. Langmuir 24:7354-7364

Handy RD, Owen R, Valsami-Jones E (2008) The ecotoxicology of nanoparticles and nanomaterials: current status, knowledge gaps, challenges, and future needs. Ecotoxicology 17:315-325

Hsu YW, Tsai CF, Chuang WC, Chen WK, Ho YC, Lu FJ (2010) Protective effects of silica hydride against carbon tetrachloride-induced hepatotoxicity in mice. Food Chem Toxicol 48:1644-1653

Kaegia R, Wagner T, Hetzer B, Sinnet B, Tzvetkov G, Boller M (2008) Size, number and chemical composition of nanosized particles in drinking water determined by analytical microscopy and LIBD. Water Res 42:2778-2786

Kaneto H, Fujii J, Myint T, Miyazawa N, Islam KN, Kawasaki Y, Suzuki K, Nakamura M, Tatsumi H, Yamasaki Y, Taniguchi N (1996) Reducing sugars trigger oxidative modification and apoptosis in pancreatic $\beta$-cells by provoking oxidative stress through the glycation reaction. Biochem J 320:855-863

Keller WD, Feder GL (1979) Chemical analysis of water used in Hunza, Pakistan. In: Hemphill DD (ed) Trace Substances in Environmental Health XIII: Proceedings. University of Misssouri-Columbia, MO., pp 130-137

Kimberly L, Lloyd P, Wasmund W, Smith L, Raven PB (2001) Clinical effects of a dietary antioxidant silicate supplement, microhydrin, on cardiovascular responses to exercise. J Med Food 4:151-159

Kitagawa Y, Liu C, Ding X (2011) The influence of natural mineral water on aquaporin water permeability and human natural killer cell activity. BBRC 409:40-45

Lenzen S (2008) The mechanisms of alloxan- and streptozotocin-induced diabetes. Diabetologia 51:216-226

Lenzen S, Munday R (1991) Thiol-group reactivity, hydrophilicity and stability of alloxan, its reduction products and its $\mathrm{N}$-methyl derivatives and a comparison with ninhydrin. Biochem Pharmacol 42:1385-1391

Lenzen S, Drinkgern J, Tiedge M (1996) Low antioxidant enzyme gene expression in pancreatic islets compared with various other mouse tissues. Free Radic Biol Med 20: 463-466

Li YP, Nishimura T, Teruya K, Maki T, Komatsu T, Hamasaki T, Kashiwagi T, Kabayama S, Shim SY, Katakura Y, Osada K, Kawahara T, Otsubo K, Morisawa S, Ishii Y, Gadek 
Z, Shirahata S (2002) Protective mechanism of reduced water against alloxan-induced pancreatic $\beta$-cell damage: scavenging effect against reactive oxygen species. Cytotechnology 40:139-149

Li YP, Hamasaki T, Nakamichi N, Kashiwagi T, Komatsu T, Ye J, Teruya K, Abe M, Yan H, Kinjo T, Kabayama S, Kawamura M, Shirahata S (2011) Suppressive effect of electrolyzed reduced water on alloxan-induced apoptosis and type 1 diabetes mellitus. Cytotechnology 63:119-131

Lortz S, Tiedge M (2003) Sequential inactivation of reactive oxygen species by combined overexpression of SOD isoforms and catalase in insulin-producing cells. Free Radic Biol Med 34:683-688

Lortz S, Gurgul-Convey E, Lenzen S, Tiedg M (2005) Importance of mitochondrial superoxide dismutase expression in insulin-producing cells for the toxicity of reactive oxygen species and proinflammatory cytokines. Diabetologia 48: 1541-1548

Lowry OH, Rosebrough NJ, Farr AL, Randall RJ (1951) Protein measurement with the Folin phenol reagent. J Biol Chem 193:269-275

Mani SS, Subramanian IP, Pillai SS, Muthusamy K (2010) Evaluation of hypoglycemic activity of inorganic constituents in Nelumbo nucifera seeds on streptozotocin-induced diabetes in rats. Biol Trace Elem Res 138:226-237

Nathan DM (2007) Finding new treatments for diabetes-how many, how fast... how good? N Engl J Med 356:437-440

Nicoletti I, Migliorati G, Pagliacci MC, Grignani F, Riccardi C (1991) A rapid and simple method for measuring thymocyte apoptosis by propidium iodide staining and flow cytometry. J Immunol Methods 139:271-279

Nicolls MR, Haskins K, Flores SC (2007) Oxidant stress, immune dysregulation, and vascular function in type I diabetes. Antioxid Redox Signal 9:879-889

Nissen SE, Wolski K (2007) Effect of rosiglitazone on the risk of myocardial infarction and death from cardiovascular causes. N Engl J Med 356:2457-2471

Oda M, Kusumoto K, Teruya K, Hara T, Maki S, Kabayama S (1999) Electrolyzed and natural reduced water exhibit insulin-like activity on glucose uptake into muscle cells and adipocytes. In: Bernard A, Griffiths B, Noe W, Wurm F (eds) Animal cell technology: products from cells, cells as products, vol 10. Kluwer, The Netherlands, pp 425-427

Rylander R (2008) Drinking water constituents and disease. J Nutr 138:423S-425S

Sakurai K, Katoh M, Someno K, Fujimoto Y (2001) Apoptosis and mitochondrial damage in INS-1 cells treated with alloxan. Biol Pharm Bull 24:876-882

Sales CH, de Fatima Campos Pedrosa L (2006) Magnesium and diabetes mellitus: their relation. Clin Nutr 25:554-562

Shirahata S, Nishimura T, Kabayama S, Aki D, Teruya K, Otsubo K, Morisawa S, Ishii Y, Gadek Z, Katakura Y (2001)
Anti-oxidative water improves diabetes. In: Linder-Olsson E, Chatzissavidou N, Lüllau E (eds) Animal cell technology: from target to market, vol 12. Kluwer, The Netherlands, pp 574-577

Soltani N, Keshavarz M, Minaii B, Mirershadi F, Asl SZ, Dehpour AR (2005) Effects of administration of oral magnesium on plasma glucose and pathological changes in the aorta and pancreas of diabetic rats. Clin Exp Pharmacol Physiol 32:604-610

Stephanson CJ, Flanagan GP (2003a) Antioxidant capacity of silica hydride: a combinational photosensitization and fluorescence detection assay. Free Radic Biol Med 35: $1129-1137$

Stephanson CJ, Flanagan GP (2003b) Synthesis of a novel anionic hydride organosiloxane presenting biochemical properties. Int J Hydrogen Energy 28:1243-1250

Stephanson CJ, Flanagan GP (2004) Non-toxic hydride energy source for biochemical and industrial venues: ORP and $\mathrm{NAD}^{+}$reduction analyses. Int $\mathrm{J}$ Hydrogen Energy 29: 459-464

Szkudelski T (2001) The mechanism of alloxan and streptozotocin action in B cells of the rat pancreas. Physiol Res 50:537-546

Takasu N, Asawa T, Komiya I, Nagasawa Y, Yamada T (1991) Alloxan-induced DNA strand breaks in pancreatic islets. J Biol Chem 266:2112-2114

Tubek S (2006) Role of trace elements in primary arterial hypertension. Biol Trace Elem Res 114:1-5

Valko M, Leibfritz D, Moncola J, Cronin MTD, Mazura M, Telser J (2007) Free radicals and antioxidants in normal physiological functions and human disease. Int J Biochem Cell Biol 39:44-84

Vassort G, Turan B (2010) Protective role of antioxidants in diabetes-induced cardiac dysfunction. Cardiovasc Toxicol 10:73-86

Wagner T, Bundschuhb T, Schick R, Köster R (2004) Detection of aquatic colloids in drinking water during its distribution via a water pipeline network. Water Sci Technol 50:27-37

Wigginton NS, Haus KL, Hochella MF Jr (2007) Aquatic environmental nanoparticles. J Environ Monit 9:13061316

Yamamoto H, Uchigata Y, Okamoto H (1981) Streptozotocin and alloxan induce DNA strand breaks and poly (ADPribose) synthetase in pancreatic islets. Nature 294:284-285

Yaturu S, Bryant B, Jain SK (2007) Thiazolidinedione treatment decreases bone mineral density in type 2 diabetic men. Diabetes Care 30:1574-1576

Zhang H, Ollinger K, Brunk U (1995) Insulinoma cells in culture show pronounced sensitivity to alloxan-induced oxidative stress. Diabetologia 38:635-641 